\title{
Global DNA Methylation in Rats' Liver Is Not Affected by Hypercholesterolemic Diet
}

\section{Lucie JURCIKOVA-NOVOTNA ${ }^{1}$, Lenka MRAZOVA ${ }^{1}$, Kateřina MIČOVÁ ${ }^{2,3}$, David FRIEDECKÝ ${ }^{2,3}$, Jaroslav A. HUBACEK ${ }^{1}$, Rudolf POLEDNE ${ }^{1}$}

${ }^{1}$ Center for Experimental Medicine, Institute for Clinical and Experimental Medicine, Prague, Czech Republic, ${ }^{2}$ Laboratory for Inherited Metabolic Disorders, University Hospital Olomouc, ${ }^{3}$ Laboratory of Metabolomics, Institute of Molecular and Translational Medicine, Faculty of Medicine and Dentistry, Palacký University Olomouc, Czech Republic

Received September 18, 2019

Accepted January 21, 2020

Epub Ahead of Print March 23, 2020

\section{Summary}

Increased plasma cholesterol levels are listed between the major atherosclerosis risk factors. The final plasma cholesterol levels result from the interplay between the genetic and environmental (diet, physical activity) factors. Little is known, how dietary factors influence epigenetics. We have analyzed, if an overgeneration feeding of rat with cholesterol influences total liverDNA methylation, and if total liver-DNA methylation differ between the different rat strains (Prague hereditary hypercholesterolemic rats, Prague hereditary hypertriglyceridemic rats and Wistar Kyoto rats). The animals were feed with high fat (additional $5 \%$ over normal capacity) high cholesterol (2\%) diet for 14 days. DNA methylation in the liver tissue in different generations was analyzed using the liquid chromatography coupled with tandem mass spectrometry. We have not observed any significant changes in total liver-DNA methylation over the 9 generations of animals feed by fat/cholesterol enriched diet. Additionally, there were no differences in DNA methylation between different rat strains. In animal model, the dietary changes (hypercholesterolemic diet) not significantly influence the total DNA methylation status within the liver.

\section{Key words}

Rat $\bullet$ Cholesterol $\bullet$ Diet $\bullet$ Liver $\bullet$ DNA Methylation

\section{Corresponding author}

Hubacek JA, CEM, IKEM, Videnska 1958/9, 14021 Prague, Czech

Republic. Email: jahb@ikem.cz

\section{Introduction}

Atherosclerosis is a chronic inflammatory disease, developing for decades by an accumulation of lipids and fibrous elements and activation of monocytemacrophages in the arterial vascular wall (Lusis 2000). Although recent results are conflicting (Hubacek et al. 2017a, Pikhart et al. 2015), dyslipidemia (total cholesterol over $5 \mathrm{mmol} / \mathrm{l}$ and triglycerides over $1.7 \mathrm{mmol} / \mathrm{l}$ ) is believed to be a one of the major risk factors of atherosclerosis development. Excess of low density lipoprotein (LDL) particles initiate the cascade of inflammatory response in large and medium-sized arteries (Hansson 2005).

Predisposition to atherosclerosis has multifactorial background, results from interactions between various genes and between genes and environmental factors. It was approved that environment, behavior and therapeutic are important epigenetic determinants (Segal et al. 2017, Lévesque et al. 2014). The factors like smoking (Breitling et al. 2011), unhealthy diet, drugs (Bahl et al. 2015) and also aging (Bollati et al. 2009, Wong et al. 2010) were linked with aberrant DNA epigenetic pattern. Epigenetic focus on DNA non-sequence heredity and comprises alterations in chromatin structure, such as DNA methylation (most intensively studied), histone modification, nucleosome positioning and regulatory RNAs (Portela and Esteller

PHYSIOLOGICAL RESEARCH • ISSN 1802-9973 (online) 
2010, Dlouha and Hubacek 2017). In contrast to stable DNA sequence, epigenetic modifications are dynamic and occur during development and differentiation of the cells. They possibly result in alterations in transcriptional and post-transcriptional gene expression among the cell types (Ferguson-Smith 2011).

In mammals is DNA methylation catalyzed by DNA methyltransferases (DNMTs), which transfer a methyl group from S-adenosylmethionin to the 5-carbon of cytosine residue forming 5-methylcytosine (Hermann et al. 2004). DNA demethylation is more complicated process occurring passively through the inhibition of DNMTs or actively by several mechanisms including enzymatic catalyzes and DNA repair (for review see Wang et al. 2014). DNA methylation associated with the transcriptional silencing occurs mainly in CpG islands (Vinson \& Chatterjee 2012) of the promoters and $\mathrm{CpG}$ island shores (Irizarry et al. 2009), since less common methylation of gene body leads to increase of transcription of highly expressed genes (Jjingo et al. 2012). Though, CpG islands of the genes' promoters occupy only $2 \%$ of the genome and are usually unmethylated. The main portion of $\mathrm{CpG}$ methylation in the genome represents transposable elements (TEs - DNA sequences with the ability to move through the genome, sources of transcriptional factors and non-coding regulatory miRNAs) (Chuong et al. 2017), TEs comprise at least $50 \%$ of the genome and are heavily methylated (Slotkin \& Martienssen 2007).

Animal models in atherosclerosis of hypercholesterolemia in rat had been developed in the 80 s after long term brother-sister inbreeding of Wistar rat and testing to the high fat high cholesterol diet (HCD). A new phenotype appeared in the $8^{\text {th }}$ generation (Befekadu et al. 1992, Kovář et al. 2009, Poledne and Jurčíková-Novotná 2017). The hypercholesterolemia in these Prague hereditary hypercholesterolaemic (PHHC) rats is induced only by HCD without any addition of bile salts and/or antithyroid drugs and reaches the cholesterol concentration between $8-10 \mathrm{mmol} / \mathrm{l}$. The identical experiment was repeated in $90 \mathrm{~s}$ with the similar results (Poledne, unpublished data). The microarray analysis of hepatic transcriptome of PHHC and Wistar rats cannot explain the hypercholesterolemia in PHHC rats (Vlachová et al. 2014) albeit some single genes, as cholesterol 7 a-hydroxylase (Hubacek \& Bobkova 2006) seems to be of importance (Hubacek et al. 2008). According to previous results and our knowledge, we have suggested that HCD diet in rats may alter the epigenome of the offspring and therefore contribute to hypercholesterolemia development.

Here we report longitudinal analysis of global liver DNA methylation in animal rat model. The animals were fed with high-fat high-cholesterol (HCD) diet and positive selected according to increasing total serum cholesterol in nine generations.

Wistar rats (AnLAb, Prague, Czech Republic) were fed with the hypercholesterolemic diet (HCD) obtaining $2 \%$ cholesterol and $5 \%$ palm kernel oil for 14 days. The total cholesterol (TC) in serum was measured twice, before HCD feeding and one day prior to return to standard chow diet. Parent generation (6 males and 6 females) was selected from Wistar rats $(\mathrm{N}=50)$ with the highest induced cholesterolemia, followed by brothersister inbreeding up to $9^{\text {th }}$ generation.

Further, age-matched of Prague hereditary hypercholesterolaemic rats (PHHC, N=6), Prague hereditary hypertriglyceridemic rats (HTG, N=6) and Wistar Kyoto rats (WKY, N=6) were used for comparisons. These animals were on standard laboratory diet (chow without any thyroid toxic or hepatotoxic factors).

All animals were sacrificed by rapid decapitation, their blood was collected directly from opened carotid arteries for TC analysis. Livers were immediately excised and frozen and stored at $-20^{\circ} \mathrm{C}$. The experimental protocol of the study and all animal care were approved by the Institutional ethics committee and were in compliance with the State Veterinary Administration.

Total cholesterol was measured in serum using enzymatic kits (Roche Diagnostics, Basel, Switzerland). Genomic DNA was isolated from the frozen liver. Briefly $50 \mathrm{mg}$ of rat liver were homogenized and incubated with RNase $\mathrm{A}$ and proteinase $\mathrm{K}$ and lysis buffer overnight followed by standard salting out method (Miller et al. 1988). DNA concentration was determined on NanoDrop spectrophotometer, the $A 260 / A 280$ ratio was between 1.8 and 2.0. One $\mu \mathrm{g}$ of genomic DNA samples were enzymatically hydrolyzed at least 3 hours to individual deoxyribonucleosides by DNA Degradase Plus (Epigentek, Farmingdale, NY, USA) followed manufacturer protocol. We used the high sensitivity method for the determination of the global DNA methylation levels, the liquid chromatography coupled with tandem mass spectrometry (LC-MS/MS). Both calculation modes, the ratio of 5-methyl-2'-deoxycitidine $(5 \mathrm{mdC})$ to 2 -deoxyguanosine $(\mathrm{dG})$ and the ratio of $5 \mathrm{mdC}$ 
versus sum of $5 \mathrm{mdC}$ and 2 '-deoxycitidine $(\mathrm{dC})$, were used for the quantification of DNA methylation levels. Chromatographic separation was achieved with hydrophilic interaction liquid chromatography using an Ultimate 3000 RS (ThermoFisher Scientific, MA, USA). The aminopropyl column (Luna NH2 $3 \mu \mathrm{m} 100 \AA$, $100 \mathrm{x}$ $2 \mathrm{~mm}$, Phenomenex, Torrance, USA) was maintained at $35^{\circ} \mathrm{C}$. The mobile phase consisted of $20 \mathrm{mM}$ ammonium acetate in water at $\mathrm{pH} 9.75$ (mobile phase $\mathrm{A}$ ) and acetonitrile (mobile phase $\mathrm{B}$ ). The gradient elution was performed as follows: $\mathrm{t}=0.0-3.0,80 \% \mathrm{~B}, \mathrm{t}=5.0-6.8,10 \%$ $\mathrm{B}, \mathrm{t}=7.8-10.0,95 \% \mathrm{~B}$. The flow rate was set to 0.3 $\mathrm{ml} / \mathrm{min}$, and the injection volume was $5 \mu \mathrm{l}$. MS measurement was carried out a electrospray ionization in polarity switching mode of $+5500 /-4500 \mathrm{~V}$, temperature of ion source was $400{ }^{\circ} \mathrm{C}$, curtain gas $40 \mathrm{psi}$, collision gas at 8 psi and both ion source gases 40 psi. Data acquisition and quantitation were performed using Analyst 1.6.2 and MultiQuant 3.0 software (Sciex, Foster City, CA, USA).

Contrary to the original experiment from 90s (Befekadu et al. 1992) when stimulated cholesterolemia increased moderately and continuously up to $4^{\text {th }}$ generation in both genders, in this time the effect of HDC was immediately in generation F1, but did not increased significantly after that and only slightly differ in selected females with the highest levels in generations three $(9.37 \pm 1.16 \mathrm{mmol} / \mathrm{l})$ and six $(8.86 \pm 0.72 \mathrm{mmol} / \mathrm{l})$. The global DNA methylation (expressed as \% of methylated C - \% 5mdC) in Wistar rat feed with HCD measured in first $\mathrm{F} 1$ and last $\mathrm{F} 9$ generations and in generations with highest cholesterol after HCD diet F3 and F6 did not significantly differ as well (Fig. 1).

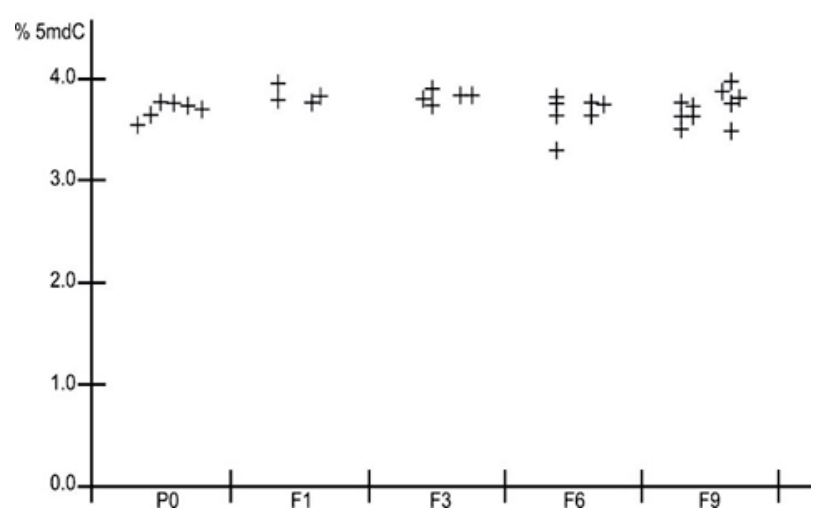

Fig. 1. Liver DNA global methylation in Wistar Kyoto rats on high fat - high cholesterol diet. DNA methylation in each animal sample of generations P0, F1, F3, F6 and F9 is expressed as $\% 5 \mathrm{mdC}$.
The average cholesterolemia in different rat strains without HCD was $2.23 \pm 0.19 \mathrm{mmol} / 1$ in PHHC $(\mathrm{N}=5), 2.34 \pm 0.09 \mathrm{mmol} / \mathrm{l}$ in WKY $(\mathrm{N}=6)$ and $2.00 \pm$ $0.17 \mathrm{mmol} / 1$ in HTG $(\mathrm{N}=6)$ and do not significantly differ between the strains. The differences were not observed among the compared animals in global liver-DNA methylation likewise (Fig. 2).

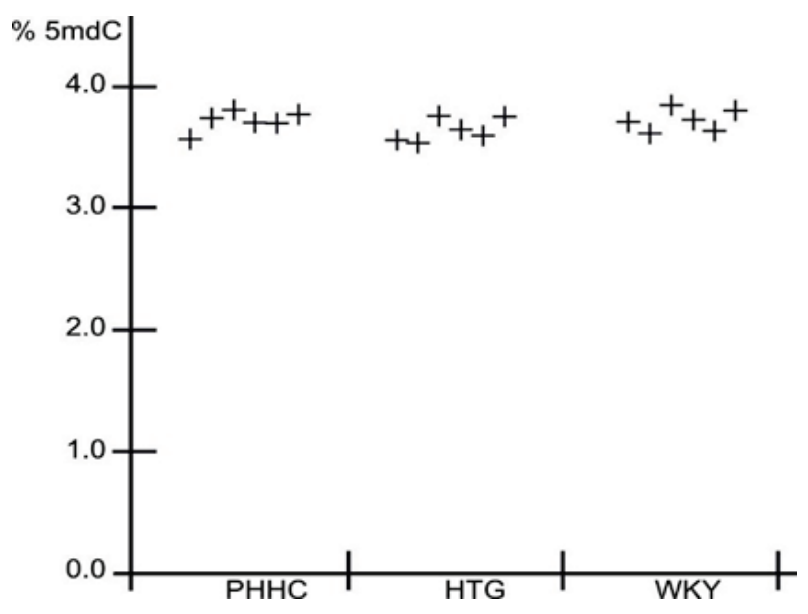

Fig. 2. Liver DNA global methylation in different rat strains (Wistar Kyoto rats - WKY, Prague hereditary hypercholesterolaemic rats - PHHC and Prague hereditary hypertriglyceridemic rats - HTG). DNA methylation in each animal sample is expressed as $\% 5 \mathrm{mdC}$.

The LC-MS/MS method is accurate and suitable method for the global DNA methylation measuring. The calculation models differ constantly in each measurement of each sample with the ratio $0.71 \pm 0.07$. The difference is due to different ion suppression effects on the fast $5 \mathrm{mdC}$ and slow eluting dG compounds (Li and Franke 2011).

DNA methylation is the most studied epigenetic modification. The associations between global DNA methylation and hypercholesterolemia were studied in humans with different methods, and with very inconsistent results (Pearce et al. 2012, Nicoletti et al. 2016, Kato et al. 2012, Cash et al. 2011). Also atherosclerosis and cardiovascular disease are associated with global DNA methylation changes (Baccarelli et al. 2010, Khyzha et al. 2017, Wang et al. 2017).

The dietary impact on atherosclerosis development was observed in offspring of hypercholesterolemic mothers (Napoli et al. 2002). Also, maternal undernutrition during the fetal development leads to atherosclerosis in progeny (Yates et al. 2009) and it was shown, that protein restriction up-regulates the cholesterol transport in placenta (Daniel et al. 2016). Therefore, it was suggested that the different diets may affect an epigenetic modification of the genome. 
Our experimental study did not support the idea, that a high fat/high cholesterol diet could extensively affect total liver-DNA methylation and influence plasma lipid levels through this regulatory mechanism.

Further, as the total liver-DNA methylation was almost identical within the different rat strains, we suggest that the total DNA analysis is not sufficiently precise to distinguish between the potential different DNA methylation or to be associated with different phenotypes. Likely the DNA methylation of all genes involved in lipid metabolism needs to be examined separately to descry its potential link between diet DNA methylation and plasma cholesterol levels.

In comparison with the most studies published so far, we have analyzed DNA methylation within the liver tissue (and not in leucocytes) - which is the major source of lipoprotein particles - thus, the liver is expected to be target organ for the dietary induced hypercholesterolemia. But we cannot exclude, that there could be some changes in DNA methylation occurring in other tissues, as there are significant DNA methylation differences between the different tissues (Voisin et al. 2015, Leenen et al. 2016).

As the previous experiments exclude also the major role of differences in transcriptome (Vlachová et al. 2014) as a determinant of PHHC-rat phenotypes, the last possibility how the cholesterol in these animals is influenced is a role of accumulation of many single nucleotide polymorphisms, similarly as in humans (Hubacek et al. 2017b, Talmud et al. 2013, Paththinige et al. 2017), as suggested previously (Befekadu et al. 1992). If high number of cholesterol increasing SNPs is accumulated, the inbreeding crossing could conserve the sufficient negative genetic background which could be transferred into the next generations.

We conclude, that the over-generational feeding the rats with high-fat high-cholesterol diet is not influencing the total DNA methylation in rats livers.

\section{Conflict of Interest}

There is no conflict of interest

\section{Acknowledgements}

The study was supported by project 00023001 (Ministry of Health, Czech Republic) for the development of research organizations (Institute for Clinical and Experimental Medicine, Prague, Czech Republic) institutional support.

\section{References}

BACCARELLI A, WRIGHT R, BOLLATI V, LITONJUA A, ZANOBETTI A, TARANTINI L, SPARROW D, VOKONAS P, SCHWARTZ J: Ischemic heart disease and stroke in relation to blood DNA methylation. Epidemiology 21: 819-828, 2010. https://doi.org/10.1097/EDE.0b013e3181f20457

BAHL A, PÖLLÄNEN E, ISMAIL K, SIPILÄ S, MIKKOLA TM, BERGLUND E, LINDQVIST CM, SYVÄNEN AC, RANTANEN T, KAPRIO J, KOVANEN V, OLLIKAINEN M: Hormone replacement therapy associated white blood cell DNA methylation and gene expression are associated with within-pair differences of body adiposity and bone mass. Twin Res Hum Genet 18: 647-661, 2015. https://doi.org/10.1017/thg.2015.82

BEFEKADU G, KOVÁR J, POLEDNE R: High sensitivity of PHHC rat to dietary cholesterol. Physiol Res 41: 263-266, 1992.

BOLLATI V, SCHWARTZ J, WRIGHT R, LITONJUA A, TARANTINI L, SUH H, SPARROW D, VOKONAS P, BACCARELLI A: Decline in genomic DNA methylation through aging in a cohort of elderly subjects. Mech Ageing Dev 130: 234-239, 2009. https://doi.org/10.1016/j.mad.2008.12.003

BREITLING LP, YANG R, KORN B, BURWINKEL B, BRENNER H: Tobacco-smoking-related differential DNA methylation: $27 \mathrm{~K}$ discovery and replication. Am J Hum Genet 88: 450-457, 2011. https://doi.org/10.1016/j.ajhg.2011.03.003

CASH HL, MCGARVEY ST, HOUSEMAN EA, MARSIT CJ, HAWLEY NL, LAMBERT-MESSERLIAN GM, VIALI S, TUITELE J, KELSEY KT: Cardiovascular disease risk factors and DNA methylation at the LINE-1 repeat region in peripheral blood from Samoan Islanders. Epigenetics 6: 1257-1264, 2011. https://doi.org/10.4161/epi.6.10.17728

CHUONG EB, ELDE NC, FESCHOTTE C: Regulatory activities of transposable elements: from conflicts to benefits. Nat Rev Genet 18: 71-86, 2017. https://doi.org/10.1038/nrg.2016.139 
DANIEL Z, SWALI A, EMES R, LANGLEY-EVANS SC: The effect of maternal undernutrition on the rat placental transcriptome: protein restriction up-regulates cholesterol transport. Genes Nutr 11: $27,2016$. https://doi.org/10.1186/s12263-016-0541-3

DLOUHÁ D, HUBÁČEK JA: Regulatory RNAs and cardiovascular disease - with a special focus on circulating microRNAs. Physiol Res 66 (Suppl 1): S21-S38, 2017. https://doi.org/10.33549/physiolres.933588

FERGUSON-SMITH AC: Genomic imprinting: the emergence of an epigenetic paradigm. Nat Rev Gene 12: 565-575, 2011. https://doi.org/10.1038/nrg3032

HANSSON GK: Inflammation, atherosclerosis, and coronary artery disease. N Engl J Med 352: 1685-1695, 2005. https://doi.org/10.1056/NEJMra043430

HERMANN A, GOWHER H, JELTSCH A: Biochemistry and biology of mammalian DNA methyltransferases. Cell Mol Life Sci 61: 2571-2587, 2004. https://doi.org/10.1007/s00018-004-4201-1

HUBACEK JA, BOBKOVA D: Role of cholesterol 7alpha-hydroxylase (CYP7A1) in nutrigenetics and pharmacogenetics of cholesterol lowering. Mol Diagn Ther 10: 93-100, 2006. https://doi.org/10.1007/BF03256448

HUBÁCEK JA, BOBKOVÁ D, BOHUSLAVOVÁ R, POLEDNE R: Differences in expression of cholesterol 7alphahydroxylase between PHHC and Wistar rats. Folia Biol (Praha) 54: 18-23, 2008.

HUBACEK JA, STANEK V, GEBAUEROVA M, ADAMKOVA V, LESAUSKAITE V, ZALIADUONYTEPEKSIENE D, TAMOSIUNAS A, SUPIYEV A, KOSSUMOV A, ZHUMADILOVA A, PITHA J: Traditional risk factors of acute coronary syndrome in four different male populations - total cholesterol value does not seem to be relevant risk factor. Physiol Res 66 (Suppl 1): S121-S128, 2017. https://doi.org/10.33549/physiolres.933597

HUBACEK JA, ADAMKOVA V, LANSKA V, DLOUHA D: Polygenic hypercholesterolemia: examples of GWAS results and their replication in the Czech-Slavonic population. Physiol Res 66 (Suppl 1): S101-S111, 2017. https://doi.org/10.33549/physiolres.933580

IRIZARRY RA, LADD-ACOSTA C, WEN B, WU Z, MONTANO C, ONYANGO P, CUI H, GABO K, RONGIONE M, WEBSTER M, JI H, POTASH J, SABUNCIYAN S, FEINBERG AP: The human colon cancer methylome shows similar hypo- and hypermethylation at conserved tissue-specific CpG island shores. Nat Genet 41: 178-186, 2009. https://doi.org/10.1038/ng.298

JJINGO D, CONLEY AB, YI SV, LUNYAK VV, JORDAN IK: On the presence and role of human gene-body DNA methylation. Oncotarget 3: 462-74, 2012. https://doi.org/10.18632/oncotarget.497

KATO S, LINDHOLM B, STENVINKEL P, EKSTRÖM TJ, LUTTROPP K, YUZAWA Y, YASUDA Y, TSURUTA Y, MARUYAMA S: DNA hypermethylation and inflammatory markers in incident Japanese dialysis patients. Nephron Extra 2: 159-168, 2012. https://doi.org/10.1159/000339437

KHYZHA N, ALIZADA A, WILSON MD, FISH JE: Epigenetics of atherosclerosis: emerging mechanisms and methods. Trends Mol Med 23: 332-347, 2017. https://doi.org/10.1016/j.molmed.2017.02.004

KOVÁŘ J, TONAR Z, HECZKOVÁ M, POLEDNE R: Prague hereditary hypercholesterolemic (PHHC) rat - a model of polygenic hypercholesterolemia. Physiol Res 58 (Suppl 2): S95-S99, 2009.

LEENEN FA, MULLER CP, TURNER JD: DNA methylation: conducting the orchestra from exposure to phenotype? Clin Epigenetics 8: 92, 2016. https://doi.org/10.1186/s13148-016-0256-8

LÉVESQUE ML, CASEY KF, SZYF M, ISMAYLOVA E, LY V, VERNER MP, SUDERMAN M, BRENDGEN M, VITARO F, DIONNE G, BOIVIN M, TREMBLAY RE, BOOIJ L: Genome-wide DNA methylation variability in adolescent monozygotic twins followed since birth. Epigenetics 9: 1410-1421. 2014. https://doi.org/10.4161/15592294.2014.970060

LI X, FRANKE AA: High-throughput and cost-effective global DNA methylation assay by liquid chromatographymass spectrometry. Anal Chim Acta 703: 58-63, 2011. https://doi.org/10.1016/j.aca.2011.07.014

LUSIS AJ: Atherosclerosis. Nature 407: 233-241, 2000. https://doi.org/10.1038/35025203

MILLER SA, DYKES DD, POLESKY HF: A simple salting out procedure for extracting DNA from human nucleated cells. Nucleic Acids Res 16: 1215, 1988. https://doi.org/10.1093/nar/16.3.1215 
NAPOLI C, DE NIGRIS F, WELCH JS, CALARA FB, STUART RO, GLASS CK, PALINSKI W: Maternal hypercholesterolemia during pregnancy promotes early atherogenesis in LDL receptor-deficient mice and alters aortic gene expression determined by microarray. Circulation 105: 1360-1367, 2002. https://doi.org/10.1161/hc1102.106792

NICOLETTI CF, NONINO CB, DE OLIVEIRA BA, PINHEL MA, MANSEGO ML, MILAGRO FI, ZULET MA, MARTINEZ JA: DNA methylation and hydroxymethylation levels in relation to two weight loss strategies: energy-restricted diet or bariatric surgery. Obes Surg 26: 603-611, 2016. https://doi.org/10.1007/s11695-015$\underline{1802-8}$

PATHTHINIGE CS, SIRISENA ND, DISSANAYAKE V: Genetic determinants of inherited susceptibility to hypercholesterolemia - a comprehensive literature review. Lipids Health Dis 16: 103, 2017. https://doi.org/10.1186/s12944-017-0488-4

PEARCE MS, MCCONNELL JC, POTTER C, BARRETT LM, PARKER L, MATHERS JC, RELTON CL: Global LINE-1 DNA methylation is associated with blood glycaemic and lipid profiles. Int J Epidemiol 41: 210-217, 2012. https://doi.org/10.1093/ije/dys020

PIKHART H, HUBÁČEK JA, PEASEY A, KUBÍNOVÁ R, BOBÁK M: Association between fasting plasma triglycerides, all-cause and cardiovascular mortality in Czech population. Results from the HAPIEE study. Physiol Res 64 (Suppl 3): S355-S361, 2015.

POLEDNE R, JURČÍKOVÁ-NOVOTNÁ L: Experimental models of hyperlipoproteinemia and atherosclerosis. Physiol Res 66 (Suppl 1): S69-S75, 2017. https://doi.org/10.33549/physiolres.933585

PORTELA A, ESTELLER M: Epigenetic modifications and human disease. Nat Biotechnol 28: 1057-1068, 2010. https://doi.org/10.1038/nbt.1685

SEGAL NL, MONTOYA YS, LOKE YJ, CRAIG JM: Identical twins doubly exchanged at birth: a case report of genetic and environmental influences on the adult epigenome. Epigenomics 9: 5-12, 2017. https://doi.org/10.2217/epi-2016-0104

SLOTKIN RK, MARTIENSSEN R: Transposable elements and the epigenetic regulation of the genome. Nat Rev Genet 8: 272-285, 2007. https://doi.org/10.1038/nrg2072

TALMUD PJ, SHAH S, WHITTALL R, FUTEMA M, HOWARD P, COOPER JA, HARRISON SC, LI K, DRENOS F, KARPE F, NEIL HA, DESCAMPS OS, LANGENBERG C, LENCH N, KIVIMAKI M, WHITTAKER J, HINGORANI AD, KUMARI M, HUMPHRIES SE: Use of low-density lipoprotein cholesterol gene score to distinguish patients with polygenic and monogenic familial hypercholesterolaemia: a case-control study. Lancet 381: 1293-1301, 2013. https://doi.org/10.1016/S0140-6736(12)62127-8

VINSON C, CHATTERJEE R: CG methylation. Epigenomics 4: 655-663, 2012. https://doi.org/10.2217/epi.12.55

VLACHOVÁ M, HECZKOVÁ M, JIRSA M, POLEDNE R, KOVÁŘ J: The response of hepatic transcriptome to dietary cholesterol in Prague hereditary hypercholesterolemic (PHHC) rat. Physiol Res 63 (Suppl 3): S429-S437, 2014.

VOISIN S, EYNON N, YAN X, BISHOP DJ: Exercise training and DNA methylation in humans. Acta Physiol (Oxf). 213: 39-59, 2015. https://doi.org/10.1111/apha.12414

WANG KY, CHEN CC, SHEN CK: Active DNA demethylation of the vertebrate genomes by DNA methyltransferases: deaminase, dehydroxymethylase or demethylase? Epigenomics 6: 353-263, 2014. https://doi.org/10.2217/epi.14.21

WANG X, LIU AH, JIA ZW, PU K, CHEN KY, GUO H: Genome-wide DNA methylation patterns in coronary heart disease. Herz Sep 7, 2017. https://doi.org/10.1007/s00059-017-4616-8

WONG CC, CASPI A, WILLIAMS B, CRAIG IW, HOUTS R, AMBLER A, MOFFITT TE, MILL J: A longitudinal study of epigenetic variation in twins. Epigenetics 5: 516-526, 2010. https://doi.org/10.4161/epi.5.6.12226

YATES Z, TARLING EJ, LANGLEY-EVANS SC, SALTER AM: Maternal undernutrition programmes atherosclerosis in the ApoE*3-Leiden mouse. $\mathrm{Br}$ J Nutr 101: 1185-1194, 2009. https://doi.org/10.1017/S0007114508066786 